\title{
Pelatihan Kader Posyandu di Wilayah Kelurahan Kersanegara Kecamatan Cibeureum Tasikmalaya
}

\author{
Ai Cahyati ${ }^{1}$, Sofia Februanti ${ }^{2 *}$, Unang Arifin ${ }^{3}$ \\ 1,2,3Prodi Keperawatan Tasikmalaya, Poltekkes Kemenkes Tasikmalaya \\ $2^{2}$ email: sofiafebruanti@gmail.com
}

\begin{abstract}
ABSTRAK
Tujuan kegiatan pengabdian masyarakat ini adalah untuk meningkatkan upaya pemberdayaan masyarakat dalam alih informasi dan keterampilan dari petugas kepada masyarakat dan antar sesama masyarakat serta mendekatkan pelayananan kesehatan dasar terutama yang berkaitan dengan penurunan Angka Kematian Ibu (AKI), Angka Kematian Bayi (AKB), dan Angka Kematian Balita (AKABA) serta untuk mencapai tujuan Kota Sehat. Target yang ingin dicapai adalah para kader dapat meningkat pengetahuan dan keterampilannya dalam melaksanakan kegiatan posyandu secara mandiri. Metode yang digunakan adalah dengan memberikan pelatihan kader dengan jumlah jam pelatihan selama 3 hari @ 5 jam pelatihan (45 menit per jam pelatihan). Peserta adalah kader posyandu yang berada di wilayah Kelurahan Kersanegara Kecamatan Cibeureum kota Tasikmalaya sebanyak 22 orang. Kader diberikan pretest pada awal pertemuan dan post tes pada akhir pertemuan sebagai evaluasi terhadap kegiatan yang dilaksanakan. Sarana dan prasarana yang digunakan proyektor, laptop, mic, modul \& materi pelatihan kader posyandu, alat peraga posyandu, sfigmomanometer, stetoskop, timbangan, timbangan dacin, metline. Hasil kegiatan penyegaran kader adalah terjadi peningkatan pengetahuan setelah dilakukan pelatihan dengan hasil rata-rata pretest 68 , post test 80 , sehingga rata-rata peningkatan pengetahuan sebanyak 11 poin. Kader juga dapat mempraktekan Pengukuran tekanan darah, penimbangan menggunakan dacin, praktek sistem 5 meja posyandu, praktek penyuluhan dan pencatatan pelaporan. Luaran dari kegiatan pengabdian masyarakat ini adalah dihasilkannya modul dan publikasi hasil kegiatan pengabdian kepada masyarakat. Sarana dan prasarana supaya bisa dilengkapi sehingga pelayanan posyandu dapat lebih dioptimalkan. Kader posyandu lebih meningkatkan motivasi untuk melakukan penyuluhan.
\end{abstract}

Kata Kunci: pemberdayaan masyarakat, penyegaran kader, posyandu

\begin{abstract}
Purpose of this community service activity is to improve the empowerment of the community in transferring information and skills from officers to the community and among fellow citizens and to bring basic health services especially related to the reduction of maternal mortality rate (MMR), infant mortality rate (IMR) and under-five mortality rate and to achieve the goals of Healthy Cities. The target to be achieved is that cadres can increase their knowledge and skills in carrying out posyandu activities independently. The method used is to provide cadre training with the number of hours of training for 3 days @ 5 hours of training (45 minutes per hour of training). The participants were posyandu cadres in the area of Kersanagara Village, Cibeureum District, Tasikmalaya City, as many as 22 people. Cadres are given a pretest at the beginning of the meeting and post-test at the end of the meeting as an evaluation of the activities carried out. Facilities and infrastructure to be used a projector, laptop, mic, posyandu cadre training modules \& materials, posyandu props, sphygmomanometer, stethoscope, weighing scales, dacin scales, metlines. The results of cadre refresher activities were an increase in knowledge after training with an average pretest score of 68, post-test 80 , so that the average increase in knowledge was 11 points. Cadres can also practice blood pressure measurement, weighing using dacin, system posyandu 5 table practices, counseling practices, and recording reporting. The output of this community service activity is the production of modules and the publication of the results of community service activities. Facilities and infrastructure so that they can be equipped so that posyandu services can be optimized. Posyandu cadres further increase motivation to conduct counseling.
\end{abstract}

Keywords: community empowerment, cadre refreshment, posyandu 


\section{PENDAHULUAN}

Jumlah Pos Pelayanan Terpadu (Posyandu) Posyandu di Indonesia sebanyak 266.827 yang tersebar di seluruh Indonesia dan terdapat sekitar $3-4$ orang kader per posyandu dan berarti ada lebih dari 1 juta kader Posyandu (Kemenkes \& Pokjanal Posyandu Pusat, 2012). Sedangkan pada tahun 2013, jumlah posyandu yang tersebar di Indonesia mencapai lebih dari 330.000 (Ngantung, 2013). Berdasarkan data Riskesdas, hampir 78\% penimbangan balita dilaksanakan di Posyandu. Kondisi tersebut memperlihatkan peran penting dari kader Posyandu sebagai garda terdepan dalam pelayanan kepada masyarakat melalui Posyandu. Kader merupakan titik sentral dalam pelaksanaan kegiatan posyandu. Keikutsertaan dan keaktifannya diharapkan mampu menggerakkan partisipasi masyarakat. Namun, keberadaan kader relatif labil karena partisipasinya bersifat sukarela sehingga tidak ada jaminan untuk tetap menjalankan fungsinya dengan baik seperti yang diharapkan (Onthonie, Ismanto, \& Onibala, 2015).

Kader posyandu seharusnya memiliki pengetahuan dan kemampuan yang baik dalam menjalankan tugasnya. Kader Posyandu sebaiknya mampu menjadi pengelola Posyandu dengan baik karena merekalah yang paling memahami kondisi kebutuhan masyarakat di wilayahnya. Pengelola Posyandu merupakan orang yang dipilih, bersedia, mampu dan memiliki waktu serta kepedulian terhadap pelayanan sosial dasar masyarakat. Keaktifan kader dalam kegiatan posyandu berhubungan dengan pengetahuan kader, pekerjaan, tingkat pendapatan serta keikutsertaan kader pada organisasi lain (Suhat \& Hasanah, 2014). Oleh sebab itu pelatihan bagi kader posyandu merupakan salah satu upaya dalam rangka meningkatkan kapasitas dan kemampuan kader Posyandu.

Desa Kersanegara merupakan desa yang berada di wilayah kerja Puskesmas Cibeureum yang memiliki $10 \mathrm{RW}$, masing- masing RW memiliki 1 posyandu. Setiap Posyandu memiliki 5-9 orang kader, sehingga kelurahan Kersanegara memiliki jumlah total kader 59 orang. Berdasarkan studi pendahuluan, 10 posyandu di Desa Kersanegara hampir semua kader belum mendapatkan pelatihan kader posyandu. Kegiatan posyandu selama ini dilaksanakan lebih mengarah ke arah rutinitas kegiatan bulanan. Pelaksanaan posyandu belum dilaksanakan dengan sistem lima meja. Sistem lima meja yang seharusnya dilakukan di posyandu adalah berupa meja I dimulainya pendaftaran oleh kader posyandu; meja II penimbangan dan pemantauan tumbuh kembang oleh kader posyandu; meja III pengisian KMS atau buku KIA oleh kader; meja IV penyuluhan KIA menggunakan buku KIA; meja $\mathrm{V}$ pelayanan dan kesehatan dan gizi oleh petugas kesehatan. Berdasarkan fenomena tersebut di atas maka dipandang perlu untuk melakukan pelatihan bagi kader posyandu yang merupakan salah satu upaya untuk meningkatkan kapasitas dan kemampuan kader Posyandu yang pada akhirnya akan mendukung percepatan pengembangan desa dan kelurahan siaga aktif yang merupakan salah satu target kinerja yang ingin dicapai dalam proses pemberdayaan masyarakat untuk mewujudkan peningkatan kesejahteraan masyarakat.

\section{METODE}

Metode yang digunakan selama proses pembelajaran di antaranya adalah: Ceramah singkat dan tanya jawab, curah pendapat untuk penjajakan pengetahuan dan pengalaman peserta terkait dengan materi yang akan diberikan, praktek dan penugasan berupa: diskusi kelompok, studi kasus, tugas baca, bermain peran (role play), simulasi dan praktek lapangan. 


\section{HASIL DAN PEMBAHASAN}

Kegiatan penyegaran posyandu diikuti oleh perwakilan dari 11 posyandu yang ada di Kelurahan Kersanegara, masing-masing posyandu diwakili oleh dua orang orang kader, jadi jumlah total peserta adalah 22 orang. Kegiatan penyegaran posyandu ini dilakukan selama 3 hari. Berikut hasil evaluasi penyegaran kader yang dilakukan dengan pre test dan post test.

Tabel 1.

Hasil Pre Test dan Post Test Kegiatan Penyegaran Posyandu Di Posyandu Kelurahan Kersanegara Cibeureum

\begin{tabular}{ccccc}
\hline \multirow{2}{*}{ Pengetahuan } & \multicolumn{2}{c}{ Pretest } & \multicolumn{2}{c}{ Posttest } \\
\cline { 2 - 5 } & $\mathrm{N}$ & $\%$ & $\mathrm{n}$ & $\%$ \\
\hline Baik & 6 & 27,27 & 15 & 68,18 \\
\hline Cukup & 14 & 63,63 & 7 & 31,82 \\
\hline Kurang & 2 & 9,1 & 0 & 0 \\
\hline
\end{tabular}

Dari tabel 1 dapat disimpulkan bahwa pengetahuan kader posyandu setelah diberikan pelatihan penyegaran posyandu mengalami peningkatan.

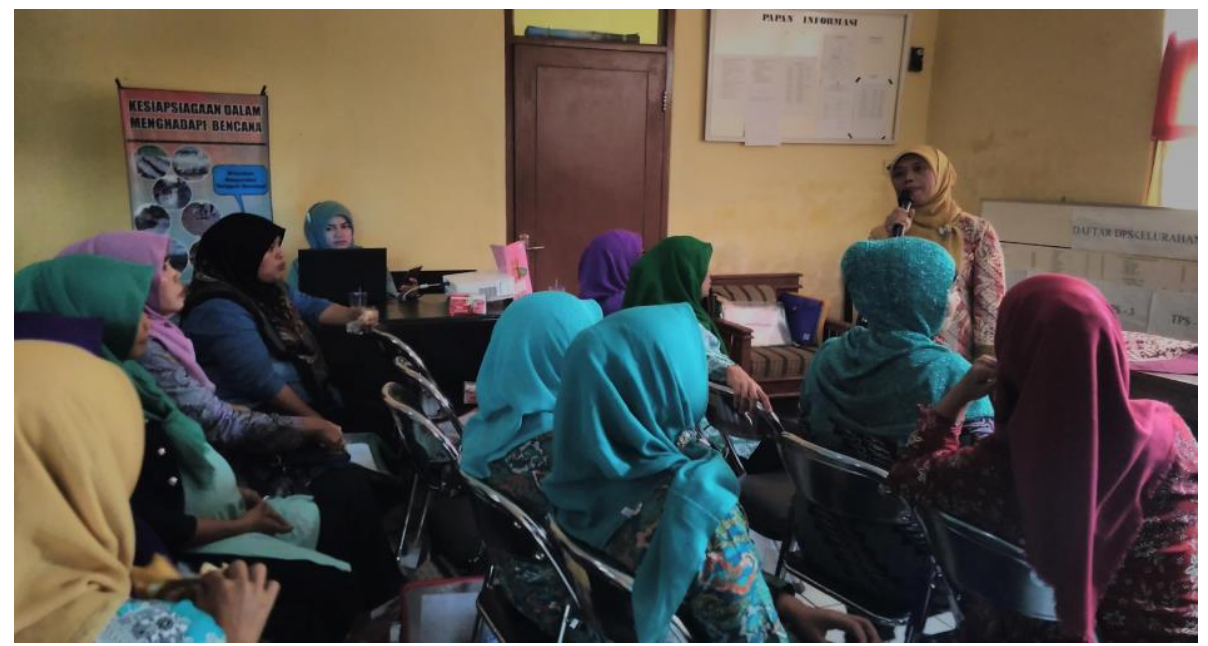

Gambar 1.

Evaluasi penyampaian materi oleh kader

Selain aspek pengetahuan kader juga dilakukan latihan praktek: Pengukuran tekanan darah, Penimbangan menggunakan dacin, praktek sistem 5 meja posyandu, praktek penyuluhan, pencatatan pelaporan. Kader dibimbing oleh mahasiswa berkelompok untuk melakukan praktek tersebut di atas, dan hasilnya sebagian besar kader dapat melakukan kegiatan praktek di atas. Setelah kegiatan pelatihan penyegaran kader selesai maka tim pengabdian masyarakat mengadakan kegiatan monitoring dan evaluasi terhadap pelaksanaan kegiatan posyandu yang dilakukan. Hasilnya sebagian besar posyandu menerapkan apa yang telah dilatih, walaupun belum optimal terkait kendala fasilitas yang dimiliki tiap posyandu seperti: Sistem 5 meja posyandu belum optimal dilaksanakan. Hal ini terjadi karena fasilitas 5 meja di posyandu tidak mencukupi, ini disiasati dengan memanfaatkan fasilitas yang ada misal meja posyandu disediakan untuk pendaftaran, pencatatan dan pelaporan saja, sedangkan yang lainnya tidak menggunakan meja tetapi areanya tetap disediakan. Selain itu, penyuluhan oleh kader belum optimal dilaksanakan, hal ini terjadi karena pada beberapa 
posyandu ada kekurangan tenaga kader, di lainnya karena kurang keberanian kader dalam melakukan penyuluhan. Sementara ini penyuluhan masih dilakukan oleh tenaga kesehatan.

Posyandu merupakan Upaya Kesehatan Bersumber Daya Masyarakat (UKBM) untuk meningkatkan hidup sehat dan sejahtera di masyarakat. Posyandu berfungsi sebagai wadah pemberdayaan masyarakat dalam alih informasi dan keterampilan dari petugas kepada masyarakat dan antar sesama masyarakat serta mendekatkan pelayanan kesehatan dasar, terutama berkaitan dengan penurunan Angka Kematian Ibu (AKI), Angka Kematian Bayi (AKB) dan Angka Kematian Balita (AKABA). Kader sebagai salah satu sub sistem dalam posyandu yang bertugas untuk mengatur jalannya program dalam posyandu, kader harus lebih tahu atau lebih menguasai tentang kegiatan yang harus dijalankan atau dilaksanakan (Wati, Khariroh, \& Indriastuti, 2012).

Terwujudnya derajat kesehatan bagi setiap orang dengan memberikan upaya pengalaman belajar atau menciptakan suatu kondisi bagi individu, keluarga, kelompok dan masyarakat dengan membuka jalur komunikasi, memberikan informasi dan melakukan edukasi untuk meningkatkan pengetahuan, sikap dan perubahan perilaku melalui pendekatan pada tokoh pimpinan dan pemberdayaan masyarakat (Nurhayati \& Apriliyanti, 2015). Revitalisasi Posyandu merupakan suatu upaya untuk meningkatkan fungsi dan kinerja Posyandu (Sari, 2018). Pelatihan dan pendampingan pada kader posyandu sangat bermanfaat bagi peningkatan pengetahuan dan keterampilan kader posyandu. Hal ini sejalan dengan yang dilakukan oleh Supriyanto (2017) tentang pelatihan dan pendampingan penggunaan Siposyandu

\section{SIMPULAN}

Setelah dilakukan kegiatan penyegaran posyandu maka terjadi peningkatan pengetahuan kader posyandu tentang Pengelolaan Posyandu, penilaian masalah kesehatan pada sasaran posyandu, menggerakkan masyarakat, lima langkah kegiatan di posyandu, keterampilan kader dalam penyuluhan pada kegiatan posyandu, pencatatan dan pelaporan kegiatan posyandu.

\section{DAFTAR PUSTAKA}

Ngantung, D. (2013, October). Syarat Ideal Posyandu yang Profesional.

Nurhayati, S., \& Apriliyanti, R. (2015). Pemahaman kader posyandu tentang penanganan penyakit demam berdarah di Puskesmas Tlogosari kulon Semarang. In The 2nd University Research Coloquium 2015 (pp. 631-636). Semarang: UMS.

Onthonie, H., Ismanto, Y., \& Onibala, F. (2015). Hubungan Peran serta Kader Posyandu dengan Status Gizi Balita di Wilayah Kerja Puskesmas Manganitu Kabupaten Sangihe. eJournal Keperawatan (E-Kp), 3(2).

Sari, P. (2018). Evaluasi pelaksanaan revitalisasi posyandu dan pelatihan kader sebagai bentuk pengabdian masyarakat (Studi Kasus Di Rw 06 Desa Cileles Kecamatan Jatinangor Tahun 2017). Jurnal Pengabdian Kepada Masyarakat, 2(2).

Suhat, \& Hasanah, R. (2014). Faktor- Faktor yang Berhubungan dengan Keaktifan Kader Dalam Kegiatan Posyandu (Studi Di Puskesmas Palasari Kabupaten SUbang). Jurnal Kesehatan Masyarakat, 10(1), 73-79.

Supriyanto, A. (2017). Peran teknologi informasi bagi kader posyandu dalam kegiatan pendataan KIA. In Prosiding Semnasvoktek. semnasvoktek. Retrieved from http://eproceeding.undiksha.ac.id/index.php/semnasvoktek/article/view/706

Wati, L., Khariroh, S., \& Indriastuti, R. F. (2012). Faktor kinerja kader posyandu di kelurahan Kijang Kota Kecamatan Bintan. Jurnal Keperawatan, 2(1), 98-102. 